\title{
Son Osmanlı Mebusan Meclisi Seçimlerinde Trabzon Sancağı (İttihatçı-İtilafçı Mücadelesi)
}

\author{
Aslıhan KILINÇ*
}

\begin{abstract}
$\ddot{O} \mathbf{z}$
Osmanlı Devleti'nde ilk seçimler muhassıllık meclislerinde yapılmış olsa da halk genel anlamda 1908 yılında yapılan seçimlerde seçme hakkını kullanmıştır. Buna göre Osmanlı Devleti’nde seçim sistemi iki dereceli olarak uygulanmış olup söz konusu sistem 1946 yılına kadar geçerli olmuştur. Dolayısıyla Trabzon sancağında yapılan 1919 yılı seçimleri de bu kurallar çerçevesinde gerçekleştirilmiştir. Konu ile alakalı ATASE, TITE, devlet arşivleri ve döneme ait gazetelerden tespit edilen bilgilere göre 1919 yılı seçimlerini genel anlamda Temsil Heyeti adına aday gösterilen Müdafaa-i Hukuk Cemiyeti üyeleri kazanmıştır. Buna mukabil arşiv kayıtları ve döneme ilişsin gazetelerinin aktardığına göre İttihatçı - İtilafçı mücadelesinin yaşandığı Trabzon seçimlerinde Mustafa Kemal Paşa cephesi pek üstünlük sağlayamamıştır. Seçimlerde Trabzon sancağından yedi mebus seçilmiştir. Sakizade Hasan Bey, Nafis Müsteşarl Ahmet Muhtar Bey, Reiszade Ali Şükrü, Efendizade Ali Şefik Bey, müstafi Kaymakam Hüsrev (Gerede) Bey, Ordulu İsmail Bey, Dizdarzade Eşref Bey, Son Osmanlı Mebusan Meclisi'ne seçilen mebuslardır. Bu çalışmada Arşiv belgeleri doğrultusunda Trabzon vilayetine bağlı Trabzon merkez sancağında 1919 yılı seçimlerine giden süreç ve seçimler konusu ele alınacaktır.
\end{abstract}

Anahtar Kelimeler: Osmanlı İmparatorluğu, Seçim, Trabzon Sancağı, İttihat ve Terakki Fırkası, Hürriyet ve İtilaf Frrkası.

\section{Trabzon Sanjak in the Last Ottoman Parliamentary Elections (Unionist-Entente Struggle) \\ Abstract}

Although the first elections in the Ottoman Empire were held in the councils of correspondence, the people generally used their right to vote in the elections held in 1908. Accordingly, the electoral system in the Ottoman Empire was applied in two degrees and this system was valid until 1946. Therefore, the 1919 elections held in the Trabzon sanjak, which is within our subject, were also held within the framework of these rules. According to the information obtained from ATASE, TITE, State Archives and newspapers belonging to the period, which we can reach on the subject, the 1919 elections were generally won by the members of the Defense of Rights Association, nominated on behalf of the Representation Committee. On the other hand, according to archive records and the newspapers of the period, Mustafa Kemal Pasha front did not have much advantage in the elections held in the Trabzon sanjak, where the Unionist - Entente struggle was taking place. Seven deputies were elected from the Trabzon sanjak. Sakizade Hasan Bey, Undersecretary of Nafis Ahmet Muhtar Bey, Reiszade Ali Şükrü, Efendizade Ali Şefik Bey, Müstafi District Governor Hüsrev (Gerede) Bey, Ordulu İsmail Bey, Dizdarzade Eşref Bey are the members of the last Ottoman Parliament MP. In this study, the process and elections leading to the 1919 elections in the central sanjak of Trabzon province in the light of archive documents will be discussed.

Keywords: Ottaman Empire, Election, Trabzon Sanjak, Committee of Union and Progress, Freedom and Accord Party.

Geliş/Received: 13.10 .2020

Kabul/Accepted: 26. 12. 2020

* Bu çalışma, insanlardan veri ve örnek toplamayı gerektiren, anket, inceleme, alan çalışması ve deney içeren araştırmalar 'kapsamına girmediğinden etik kurul onay belgesi gerektirmemektedir.

\footnotetext{
*Dr. Aslıhan Kılınç, asl-han-7701@ hotmail.com, https://orcid.org/0000-0001-8928-2961

(Makale türü: Araştırma makalesi)
} 


\section{Giriş}

II. Meşrutiyet'in ilanından sonra Osmanlı Devleti'nde 1919 yılı seçimleri dâhil olmak üzere dört kez seçim yapılmıştır. 1914 yılı seçimleriyle teşkil edilen Mebusan Meclisi, 1. Dünya Savaşı boyunca muhalefet olmaksızın savaş meclisi şeklinde faaliyetlerini sürdürmüştür (Akyıldız, 2003). Ancak söz konusu Meclis'in, padişah iradesi ile 21 Şubat 1918 tarihinde feshedilmesinden sonra, Ali Fuat Paşa'nın da ifade ettiği gibi "Anadolu'da tam bir anarşi hâkim", olmuştur (Boyacıoğlu, 2002). Bir tarafta savaşı kaybettiği için ağır mütareke şartlarını kabul etmek zorunda kalan İstanbul Hükûmeti, diğer tarafta ise kendi imkânları ile işgallere karşı dimdik ayakta durmaya çalışan bir Anadolu ve Mustafa Kemal Paşa cephesi mevcuttur. İstanbul Hükûmeti, mütarekede alınan kararlar yüzünden Anadolu'da yaşanan işgallere kayıtsız kalmayı tercih ederken, Mustafa Kemal Paşa ve Temsil Heyeti, işgallerin asılsız bahanelere dayandırıldığının ve seçimlerin bir an önce yapılması gerektiğinin farkındadır.

Çalışmaya esas teşkil eden 1919 yılı seçimlerinin bu şartlar altında yapılması pek de kolay olmamıştır. Bununla birlikte ATASE arşivi başta olmak üzere TITE ve devlet arşivlerinden yapılan incelemelerde Trabzon sancağında tıpkı diğer bölgelerde yapılan seçimlerde olduğu gibi işgallerin yanı sıra İttihatçı-İtilafçı mücadelesinin yaşandığı açıkça görülmektedir. II. Meşrutiyet'in ilanından sonra oldukça güçlenen İttihat ve Terakki Fırkasına muhalif bir grup ortaya çıkmış ve giderek güçlenmiştir. İttihatçılar yönetimde etkili tek güç olsa da parti içinde ve dışında muhaliflerin sayısı giderek artmıştır. Muhaliflerin 21 Kasım 1911 yılında, İttihat ve Terakki Fırkasına karşı kurulmuş olan Hürriyet ve İtilaf Fırkası etrafında toplanmasıyla durum endişe verici bir hal almıştır. Böylece uzun yıllar devam edecek olan İttihatçı-İtilafçı mücadelesi başlamış, özellikle ileriki dönemlerde yapılacak olan seçimlerde söz konusu çekişme büyük oranda hissedilmiştir. Ahmet Tunç'un kaleme aldığı, iki fırka arasında yaşanan çekişmeyi dönemin basınında yer alana haberlere göre genel anlamda değerlendiren "Alemdâr Gazetesine Göre İstiklâl Savaşı'nda İç Politika (1919-1921)" başlıklı doktora tezi, konuyla alakalı detaylı bilgi edinilmesi açısından önemli kaynaklar arasında yer almaktadır (Tunç, 2019). Konuya ilişkin başka bir araştırma ise, iki fırka arasında yaşanılan mücadelenin başlangıcı ve sonrasında yaşanılanları ele alan Yücel Yiğit tarafından hazırlanmış "İttihat ve Terakki Fırkası Iç̧inde Parti İçi Muhalefet: Hizb-i Cedit Hareketi” adlı makaledir (Yiğit, 2014).

Sancakta yaşanan mücadelenin yanı sıra arşivlerde göze çarpan bir diğer husus da Trabzon Valisi Mehmet Galip Bey’in Temsil Heyeti’ne karşı faaliyetlerde bulunması ve İstanbul 
Hükûmeti ile birlikte hareket etmesidir. Vali açıç̧a "Hürriyet ve İtilaf Fırkası" * lehine hareket ederek Milli Mücadele esaslarını hiçe saymıştır. Döneme ait gazeteler ve hatırattan elde edilen bilgiler valinin Trabzon'daki karşıt faaliyetlerini ve yapılan seçimleri ne derece etkilediğini açıkça ortaya koymuştur. Bu bağlamda Kâzım Karabekir tarafından kaleme alınmış olan "İstiklal Harbimiz" isimli eser de arşiv kayıtlarında verilen bilgileri doğrular nitelikte bilgiler aktarmıştır. Ayrıca Trabzon'da yapılan 1919 yılı seçimlerinin Temsil Heyeti adına beklenilen şekilde sonuçlanmadığını kendisi de eserinde dile getirmiştir (Karabekir, 2016).

\section{Seçimlere Giden Süreç}

Sivas Kongresi'nin toplanması ve delege seçimi 1919 seçimlerinin ilk adımı olmuştur. Zira seçilen delegelerin birçoğu daha sonra Temsil Heyeti tarafından mebus adayı olarak gösterilmiştir. $\mathrm{Bu}$ nedenle Temsil Heyeti vilayet ve sancak merkezlerine çektiği telgraflarla, delege seçimlerini yakından takip etmeye çalışmıştır. Ayrıca delegelerin seçilmesi ve Sivas'a sağ salim varmaları için yapılması gerekenler Müdafaa-i Hukuk Cemiyeti merkezlerine ve ordu komutanlıklarına ayrıntılı olarak bildirilmiştir (TITE, 295/35000, lef: 1). Temsil Heyeti kongre için bu denli sıkı hazırlık yapmış olsa da kongreye her sancaktan delege seçilememiş, seçilenlerin ise tamamı Sivas'a ulaşamamıştır (Demiryürek, 2018).

Temsil Heyeti ve Müdafaa-i Hukuk Cemiyeti merkezleri tarafından delegelerin seçilmesi ve Sivas'a ulaşması konusu gizli tutulmaya çalışılmıştır. Buna mukabil bazı valiler delege seçilmesini ya da seçilenlerin kongreye katılmasını engellemiştir. Bu yüzden Ali Fuat Paşa mutasarrıflıklara gönderdiği telgraflarda, seçilen delegelerin Ankara'ya gelirken yanlarında tedbir amaçlı, ticaret yapmak için geldiklerini gösteren bir belge bulundurmalarını istemiştir. Zira bu belgeler delegelerin seyahatleri boyunca kimliklerini gizlemeleri açısından önemlidir (TITE, 297/82, lef: 1). Ancak alınan tüm tedbirlere rağmen Trabzon sancağından Sivas Kongresi’ne delege gönderilememiştir. Burada, Trabzon Valisi Mehmet Galip'in rolü büyüktür. O da tıpkı Konya Valisi Cemal Bey gibi İstanbul Hükûmeti yanlısıdır, dolayısıyla kongrenin toplanmasına karşıdır (Erdeha, 1975). Laz Tekâmül-i Milliye Cemiyeti gibi Milli Mücadele karşıtı cemiyetler ile iş birliği yaparak Mustafa Kemal Paşa'ya Trabzon'da Milli Mücadele'nin teşkilatlanması konusunda yanlış bilgiler aktarmıştır (Akbal, 2008; Kansu, 2019). Aslında Kâzım Karabekir Paşa, 8 Ağustos 1919 tarihinde Sivas’a çektiği bir telgrafta kongreye katılmak üzere delegelerin Trabzon'dan hareket ettiğini yazmıştır. Ancak burada delege isimleri ya da delegelerin son

\footnotetext{
* II. Meşrutiyet'in ilanından yaklaşık dokuz ay sonra yaşanan 31 Mart Olayı ile Hareket Ordusu, II. Abdülhamit'i tahttan indirmiş bu olaydan sonra İttihat ve Terakki'ye karşı tüm muhalif gruplar Hürriyet ve İtilaf Fırkası çatısı altında toplanmaya başlamıştır. Fırkanın kurucusu Miralay Sadık Bey, firkanın tek amacının İttihat ve Terakki'yi yıkmak olduğunu belirtmişse de (Tunaya,1988) hem sadrazam ve hem de Harbiye Nazırı Mahmut Şevket Paşa'nın bulunduğu otomobilin silahlı kişilerce suikasta uğramasından sonra firkanın varlığı sona ermiştir (Birinci, 1998).
} 
Aslıhan KILINÇ

Son Osmanlı Mebusan Meclisi Seçimlerinde Trabzon Sancağı

(İttihatç1-İtilafçı Mücadelesi)

durumu hakkında başka bilgi vermemiştir (Karabekir, 2016). Nitekim Sivas Kongresi'ne katılan delegeler arasında Trabzon vilayetinden dört delege bulunmaktadır. Buna mukabil dediğimiz gibi Trabzon sancağı kongreye delege gönderememiştir (Akbal, 2004). 1914 yılı Trabzon sancağı eski mebusları İzzet ve Servet Beyler, Erzurum Kongresi'nde Temsil Heyeti'ne seçilmiş olmalarına rağmen Sivas Kongresi’ne katılmayı reddetmişlerdir. Bu konu hakkında Mustafa Kemal Paşa, Kâzım Karabekir Paşa ve söz konusu iki delege arasında uzun süren yazışmalar yapılmış ancak sonuç alınamamıştır. (Özel, 1991). Nihayetinde Sivas Kongresi, 4 Eylül 1919 tarihinde toplanmış ve kongrede üzerinde durulan en önemli konu Mebusan Meclisi'nin açılması için seçimlerin bir an önce yapılması gerektiği olmuştur (Nutuk, 2016; Uyar-Korkmaz, 2015). Ayrıca kongrede İstanbul ile iletişimin kesilmesi kararı alınmış, Damat Ferit Paşa Hükûmeti'nin istifası için çalışmalara başlanmıştır (Bilgin, 2015).

\section{İstanbul'la İletişimin Kesilmesine Trabzon'dan Tepkiler ve Seçim Kararının}

\section{Alınmasi}

Mustafa Kemal Paşa, Temsil Heyeti tarafından alınan karara istinaden, 4 Eylül 1919’da Trabzon' daki telgraf başmüdürlüğü ile Giresun ve Ordu Müdafaa-i Hukuk Cemiyeti merkezlerine çektiği telgraflarda İstanbul ile haberleşme yasağına uyulmasını istemiştir. Ancak, Trabzon sancağında bu karar pek hoş karşılanmamıştır. İzzet-Servet Beylerin de aralarında bulunduğu bir grup buna karşı çıkmıştır (Özel, 1991). Ayrıca Trabzon Valisi Galip Bey'in de İstanbul'la iletişimi kesmediği, Hürriyet ve İtilaf Fırkası yanlılarını koruduğu anlaşılmıştır (Akbal, 2008). Bunun üzerine Temsil Heyeti harekete geçmiş ve Mustafa Kemal Paşa valinin istifasını istemiştir (Harp Tarihi Vesikaları Dergisi, 1989). Vali daha sonra bu faaliyetleri yüzünden Temsil Heyeti tarafından tevkif edilmiş ve yeni Vali Haydar Bey ile sancakta 1919 Mebusan Meclisi seçimleri dönemi başlamıştır (Özel, 1991).

Damat Ferit Paşa'nın baskılara dayanamayarak sağlık sorunlarını bahane edip istifa etmesinden sonra Milli Mücadele'ye daha 1lımlı bakan Ali Rıza Paşa Hükûmeti kurulmuştur (TİTE, 297/49, lef: 1; Güneş,2012; Alemdar, 1 Teşrinievvel 1335, 1). Bu istifadan oldukça memnun olan Mustafa Kemal Paşa, İstanbul Hükûmeti'ne çektiği bir telgrafta, Ali Rıza Paşa Kabinesi'nin millet tarafından sevinçle karşılandığını belirtmiştir (ATASE, ATAZB, 9/40, lef:15; ATASE, ATAZB, 34/73, lef:1). Ayrıca telgrafında yeni kabinenin milli gayelere uymas1 şartıyla destekleneceğini bildirmiş ve İstanbul'a gönderdiği bir başka dilekçe ile yeni hükûmetin bir an evvel seçim hazırlıklarına başlamasını talep etmiştir (Bilgen, 2011; ATASE, ATAZB, 9/52, lef:8). Ali Rıza Paşa Hükûmeti'nin ilk icraatı seçim kararnamesi yayınlatmak olur (TİTE, 13/17, lef:1-2). Böylece seçimler 1919 yılı sonlarına doğru başlamış (Çavdar, 2004) ve gazetelerde “Müntehib-i Saniler belirleniyor" başlı̆̆ıyla halka duyurulmuştur (İkdam, 18 Teşrinievvel 1335, 1). Genel anlamda Temsil Heyeti ve İstanbul Hükûmeti adayları (İttihatçılar-İtilafçılar) arasındaki 
mücadeleye sahne olan seçimlerin denetlenmesi için teftiş heyetleri oluşturulması kararlaştırılmıştır. Aslında İstanbul Hükûmeti'nin asıl amacı Mili Mücadele hareketini yakından takip ederek seçimleri kontrol etmektir (Alemdar, 29 Teşrinievvel 1335, 1). Bunun için iki heyet oluşturulmuştur (Karaca, 2004).

Heyetlerden Fevzi Paşa heyeti Zonguldak, Samsun, Amasya ve Tokat seçimlerini denetledikten sonra 25 Kasım'da Sivas'a geçmiştir. Sivas’ta 16 Kasım'da başlayan "Kumandanlar Toplantısl" devam etmektedir. Heyet burada Temsil Heyeti tarafindan karşılanmıştır. Toplantıda tartışılan en önemli mesele meclisin İstanbul dışında, Anadolu'da toplanması konusu olmuştur. Nitekim bütün komutanlar meclisin padişahın olduğu yerde toplanması konusunda 1srar etmiştir. Heyet Sivas'ta hazırladığı raporu İstanbul'a göndermiştir (Vakit, 29 Teşrinievvel 1335, 1; BOA, BEO. 4598/344833, lef: 1; BOA, DH. KMS. 57/37, lef: 1; Aybars, 1984). Erzurum, Erzincan ve ardından Trabzon'a geçen heyet 51 gün süren seyahati sonunda 6 Ocak'ta İstanbul'a varmış ve raporlarını teslim etmiştir. Heyetin Trabzon seçimlerine hile karıştığına dair hazırladığı rapora seçimler konusunda yer verilecektir (BOA, MV.217/129, lef: 1$)$.

\section{Seçimlerde Rumlar}

Seçimlerde İstanbul Hükûmeti'ni tedirgin eden bir mesele de gayrimüslim tebaa olmuştur. Zira seçimlerde Rum ahalisi tarafından sahte nüfus tezkiresi kullanılacağı haberi alınmıştır. Bu nedenle seçim bölgelerinde yaşanabilecek usulsüzlüklere karşı önlem alınması gerekmektedir (Yenigün, 24 Teşrinievvel 1335,3). Gayrimüslim ahalinin bazı bölgelerde seçimlerde usulsüzlük yaptığının duyulması üzerine Rum Patrikhanesi de kiliselere Rumların seçimlere katılmaması konusunda bir genelge yollamıştır (Yenigün, 26 Teşrinievvel 1335, 2). Dönemin gazeteleri ise seçim sürecinde Rumların sürekli halkı huzursuz etmek ve karışıklık çıkarmak için uğraştı̆̆ını "Tuhaf propagandacı" başlığı ile doğrulamıştır (Yenigün, 27 Teşrinievvel 1335, 2).

13 Aralık 1919'da Trabzon'dan Gümüşhane'ye oradan da Erzurum'a gitmek için hareket eden İngiliz Kaymakam Ravlinson da Trabzon'dan ayrılırken burada bulunan Rumların seçimlere katıldığını ve genel olarak Rumlara iyi davranıldığını belirtmiştir (Harp Tarihi Vesikaları Dergisi, 1954).

\section{Trabzon Sancağında Seçimlerin Başlaması}

Sancakta seçilecek mebus sayısının ve seçim bölgelerinin belirlenmesi açısından Trabzon sancağının ilgili dönemine ait idari taksimatının verilmesi uygun olacaktır. Nitekim Osmanlı Devleti'nde 1871 Vilayet Nizamnâmesi'nden sonra Sultan II. Abdülhamid'in tahtan indirildiği Nisan 1909 yılına kadar Trabzon vilayetinin idari yapısında yoğun bir hareketlilik yaşanmıştır 
Aslihan KILINÇ

Son Osmanlı Mebusan Meclisi Seçimlerinde Trabzon Sancağı

(İttihatç1-İtilafçı Mücadelesi)

(Aygün, 2010). 18 Nisan 1916'da Rusya tarafından işgal edilen vilayette, işgalden kurtarıldıktan sonra (1918) yeniden idari düzenlemeler yapılmıştır. Buna göre Milli Mücadele döneminde aynı idari yapıy1 koruyan vilayetin Trabzon, Lazistan ve Gümüşhane olmak üzere üç sancağı bulunmaktadır. Bu taksimata göre Trabzon merkez sancağının kazaları Ordu, Giresun, Tirebolu, Görele, Vakf-1 Kebir, Sürmene, Akçaabat, Of ve Cevizlik’tir (Ural, 2007). 1919 y1lı seçimleri de bu idari taksimat esas alınarak yapılmıştır. Nitekim I. Dünya Savaşı'nda sonra bölgedeki Türk nüfusunda gayrimüslim nüfusa nazaran önemli ölçüde bir azalma olmuştur (Okur, 2014). Trabzon vilayetinden Dâhiliye Nezareti'ne çekilen telgrafla savaştan evvelki nüfus ile şimdiki nüfus arasında azîm bir fark olduğu bildirilmiş ve seçimde hangi nüfusun esas alınacağı sorulmuştur (BOA, DH. ŞFR.644/34, lef: 1-2). Bunun üzerine Dâhiliye Nezareti yayımladığı genelge ile 1919 yılı seçimlerinde, 1914 yılı verilerinin esas alınmasını istemiştir (BOA, DH. İ.UM. EK. 113/10, lef: 6). Buna göre 1914 y1lı seçimlerinde Trabzon sancağından altı mebus seçilmesi gerekmektedir (Meclis-i Mebusan Zabıt Ceridesi, C. 1, D. 3, İçs.1, İn.1, 1 Mayıs 1330, 3). Nitekim Trabzon vilayeti idari taksimatında yaşanan bazı değişiklikler nedeniyle 1914 yılında nüfusu 104.858 kişi olan sancaktan, 1919 yılı seçimlerinde yedi mebus seçildiği görülmektedir (Karpat, 2010).

Mustafa Kemal Paşa, Damat Ferit'in istifasını ve hükûmetin seçim kararı almasını beklemeden seçim hazırlıklarına başlamış; bunu 15 Eylül 1919'da vilayet ve sancak merkezlerine gönderdiği genelge ile bildirmiştir. Bu genelgede ayrıca seçimlerde ne derece yol kat ettiklerini düzenli olarak Sivas'a bildirmelerini istemiştir (TITE, 18/83, lef: 1). Aynı genelge Trabzon mevki kumandanı vasıtasıyla Trabzon'a gönderilmiştir. Daha sonra Sivas'tan 17 Eylül'de tekrar bir genelge gönderilerek, sancaklarda milletin geleceğinde rol oynayabilecek, halktan oy alabilecek mebus adaylarının bir an önce belirlenmesi istemiştir. Telgrafta, bölgeden mebusluk için adayların olup olmadığı, varsa bunların kimlerin olduğu bilgisi sorulmuştur. Ayrıca adayların Müdafaa-i Hukuk Cemiyeti üyesi olup olmadıklarının araştırılması, ilgili genelgenin tüm vilayet, sancak merkezlerine gönderilmesi istenmiştir (ATASE, ATAZB, 20/206; ATASE, ATAZB, 20/206, lef: aa). Genelgenin Trabzon sancağına ulaşmasından sonra 25 Eylül 1919'da Maçka Kaymakamı Halit Bey tarafından Sivas'a bir telgraf çekilmiş ve Trabzon'dan aday olacakların listesi belirlendikten sonra Temsil Heyeti’ne gönderileceği bildirilmiştir. Ayrıca sancakta idari teşkilatlanmanın sağlanması için çalışmaların hızlandığı belirtilmiştir (ATASE, ATAZB, 23/46, lef: bi).

Temsil Heyeti’nin sancaklara gönderdiği bu genelgeden sonra, Ali Rıza Paşa Hükûmeti tarafından 7 Ekim'de seçim talimatnamesi yayınlanmış, böylece Son Osmanlı Mebusan Meclisi seçimleri resmi olarak başlamıştır (ATASE, ATAZB, 19/23, lef:1). 1919 yılı seçimlerinde ülke genelinde yaşanan İttihatçı- İtilafçı mücadelesi Trabzon vilayetinde, bilhassa Trabzon sancağında 
yapılan seçimlerde etkisini fazlasıla göstermiştir. Hatta Damat Ferit Paşa Hükûmeti'ne istifa etmeden önce, Trabzon'da ittihatçılığın oldukça yaygın olduğuna dair sürekli haberler gitmiş ve sancakta aktif olan İttihatçıların bir listesi dahi gönderilmiştir. Bu listeyi Dâhiliye Nezareti'ne isteyen, Damat Ferit Paşa Hükûmeti'nin ve İngiliz Muhipler Cemiyeti'nin önde gelen hayranlarından Hürriyet ve İtilaf Fırkası üyesi “Artin Cemal” lakaplı Konya Valisi Cemal Bey’in ta kendisidir. Konya Valisi olarak görev yaptığı yıllarda Milli Mücadele aleyhinde faaliyetlerde bulunan Cemal Bey, Trabzon'da bulunan Hürriyet ve İtilaf Fırkası üyeleriyle iş birliği yaparak Temsil Heyeti'nin bölgedeki çalışmalarını engellemeye devam etmiştir (Çelik, 2013; AkcanGeçikli, 2017).

Temsil Heyeti ve Mustafa Kemal Paşa, İstanbul Hükûmeti’nin tüm engellemelerine rağmen, sancak merkezlerine yolladıkları bildirilerle 1919 yılı seçimlerini kontrol altında tutmaya çalışmıştır. 11 Ekim 1919 tarihinde Sivas'tan Trabzon sancağına bir telgraf gönderilerek sancağa bağlı Ordu, Giresun, Tirebolu, Görele, Vakf-1 kebir, Akçaabad, Of, Sürmene, Maçka kazalarına 23 Eylül 1919'da Sivas'tan gönderilen tebliğnamenin gelip gelmediği sorulmuş ve Mebusan Meclisi seçimleri için Sivas'ta alınan kararlar bildirilmiştir. Telgrafta ayrıca Anadolu ve Rumeli Müdafaa-i Hukuk Cemiyeti'nin seçimlere gayrimeşru bir müdahalede bulunmayacağı, bu sebeple Temsil Heyeti adına kimsenin aday gösterilmeyeceği bildirilmiştir. Ancak sancakta Temsil Heyeti'nin esas ve amaçlarını kabul edenler var ise bu heyet adına adaylıklarını koyabilecekleri ve bunu Sivas'a bildirmeleri istenmiştir. Bu telgrafin ayrıca Trabzon sancağındaki tüm kazalara da gönderilmesi istenmiştir (ATASE, ATAZB, 20/206, lef: af). Mustafa Kemal Paşa'nın bu telgrafı Trabzon sancağında karşılık bulmuş ve Maçka Kaymakamı Halit Bey tarafından gönderilen cevapta sancağın seçimlerde Temsil Heyeti tarafında yer alacağı bildirilmiştir (ATASE, ATAZB, 20/206, lef: ah).

Dâhiliye Nezareti 16 Ekim 1919'da vilayet ve sancak merkezlerine seçimlerde uyulması gereken kuralları içeren bir yazı göndermiştir. Dâhiliye Nazırı Şerif Paşa imzasıyla gönderilen yazıda öncelikle memleket yararı için mebus seçimlerinin kanunlar ve tarafsızlık ilkesi çerçevesinde yapılması gerektiği vurgulanmış ve seçmenlerin hiçbir etki altında kalmadan oylarını kullanmaları gerektiği belirtilmiştir. Bununla birlikte seçimleri denetlemek için merkezden müfettişler gönderileceği de duyurulmuştur. Askeri ve mülki memurların, siyasi fırkaların, cemiyetlerin kendi adaylarını kazandırmak amacıyla nüfuz kullanmalarına, vazifelerini ihmal etmelerine firsat verilmemesi de bilhassa tembihlenmiştir. Yazının devamında, seçimlerin son derece önemli olduğu, milli hukuku muhafaza ve müdafaa için seçilecek mebusların, vatanın saadet ve selameti endişesiyle hareket eden namuslu, iffetli ve hamiyet erbabı kişiler olması gerektiği belirtilmiştir (BOA, DH. İ.UM. EK. 114/39, lef: 5). 
Aslıhan KILINÇ

Son Osmanlı Mebusan Meclisi Seçimlerinde Trabzon Sancağı

(İttihatç1-İtilafçı Mücadelesi)

Dâhiliye Nezareti gibi Mustafa Kemal Paşa da vilayet ve sancak merkezlerinde kurulan

Müdafaa-i Hukuk Cemiyeti merkezleri ile yaptığı görüşmelerle seçim konusunu büyük bir titizlikle takip etmektedir. Zira Mustafa Kemal Paşa'ya göre seçimin başarıya ulaşması, Milli Mücadele taraftarı kişilerin seçilmesine bağlıdır. Bu yüzden 1919 yılı seçimlerinde adayların çoğunluğu Temsil Heyeti adına seçilmelidir. Bu nedenle bazı bölgelerde Temsil Heyeti tarafından seçimlere direkt müdahale edilmiş ve mebus olması istenen şahısların kazanması için çalışılmıştır (ATASE, ATAZB, 20/206, lef: bo; ATASE, ATAZB, 2/131, lef:1).

Temsil Heyeti'nin çalışmaları tamamlanmış ve sancaktan aday gösterilen ilk isim Binbaşı Hüsrev Bey olmuştur. Trabzon'da 15. Fırka Kumandanı Halit Bey’e ulaştırılmak üzere, 21 Ekim 1919 tarihinde Sivas'tan Eskişehir mutasarrıflığına bir telgraf gönderilerek, daha önce 13 Ekim 1919 tarihli telgrafta adaylığı yasaklanan Binbaşı Hüsrev (Gerede) Bey’in, Temsil Heyeti adına Trabzon sancağından adaylığını koymasının uygun olduğu bildirilmiştir. Üç bölümden oluşan aynı telgrafta Mustafa Kemal Paşa'nın yakın çevresindeki isimlerden birisi olan Hüsrev Bey'in aynı zamanda Eskişehir'den de adaylığını koyması istenmiştir. Görüldüğü üzere sancakta seçim hazırlıkları hızlanmış ve adaylar belli olmaya başlamıştır (ATASE, ATAZB, 20/206, lef: bf).

Hüsrev Bey’in aday gösterilmesinden sonra Kaymakam Halit Bey 11 Kasım 1919’da Sivas'a, Mustafa Kemal Paşa'ya bir telgraf göndererek seçimler hakkında malumat vermiş ve devamında meclisin İstanbul dışında toplanması konusunda fikirlerini beyan etmiştir. Seçimlerin başlamasıyla gündeme gelen bu önemli konu hem İstanbul Hükûmeti'ni hem de Temsil Heyeti'ni oldukça uğraştırmıştır. Nitekim Halit Bey telgrafinda meclisin İstanbul'da toplanması halinde İngilizler tarafından işgal edileceğini ve aralarında meclisi feshettirmek için çareler arayan vicdanı satılmış firkalar bulundukça İngilizlerin buna muvaffak olacağını belirtmiştir. Halit Bey de tıpkı Mustafa Kemal Paşa gibi olacakları önceden tahmin etmiştir. Zira meclisin İstanbul'da toplanmasını başta Mustafa Kemal Paşa olmak üzere Müdafaa-i Hukuk Cemiyeti üyeleri kati suretle istememektedir. Halit Bey'e göre eğer meclis İstanbul'da toplanırsa meclis işgal edilecek, millet başsız kalacak ve mebuslar tutuklanarak hapsedilecektir. Halit Bey telgrafinda ayrıca meclisin işgalinden sonra tutuklanacak mebusların İttihatçılıkla suçlanarak Malta'ya sürüleceğini de belirtmiştir (ATASE, ATAZB, 20/206, lef:ag; ATASE, ATAZB, 20/206, lef: ah).

Halit Bey, 15 Kasım'da Mustafa Kemal Paşa'ya tekrar bir telgraf göndermiş ve Trabzon Heyet-i Temsiliye merkezinde meclisin İstanbul'da toplanması konusunda anlaşmazlık çıktığını, yine de meclisin İstanbul'da toplanmasının uygun görüldüğünü bildirmiştir (ATASE, ATAZB, 23/46, lef: aj). Trabzon Müdafaa-i Hukuk Cemiyeti Reisi adına Kâzım Karabekir'e gönderilen bir telgrafta meclisin İstanbul'da toplanmasının daha uygun olacağı açıklanmıştır (ATASE, ATAZB, 20/206, lef: ap; ATASE, ATAZB, 20/206, lef: apa). 20 Kasım 1919 tarihinde cemiyet adına Hayri Bey, Mustafa Kemal Paşa'ya Trabzon ahalisi olarak hemfikir olduklarını bildirilmiştir. Bununla 
birlikte meclisin toplanma konusu dışında Milli Mücadele esaslarını aynı şekilde benimsediklerini de eklemiştir (ATASE, ATAZB, 23/46, lef: ci).

Bu durum elbette Temsil Heyeti ve Mustafa Kemal Paşa cephesinin hoşuna gitmemiştir. Ayrıca Trabzon Heyet-i Temsiliye merkezinde fikir ayrılıklarının yaşanıyor olması yapılan seçimlere de yansıyacaktır. Görüldüğü üzere Trabzon sancağında seçim konusu kadar İttihatİtilaf mücadelesi de ön plana çıkmıştır.

Kasım ayının ortalarına gelinmiş ve sancaktan yeni adaylar belli olmuştur. Çanakkale Mevki Müstahkem Kumandanı Miralay Şevket Bey tarafindan “Nuh Beye” şifresiyle bizzat Mustafa Kemal Paşa'nın kendisine gönderdiği şifrede “Millî Türk Fırkasının namzedleri listesi ber-vech-i âyi ma'rûzdur. Evvelce takdim edilen sosyalist namzedlerin nazar-ı dikkate alınması mercûdur efendim... Hamdi Bey Türk Dünyası muharriri Trabzon..." notuyla Hamdi Bey'in Trabzon sancağından seçilmesi gerektiğini bildirmiştir. Telgrafında ayrıca Milli Türk Fırkası adına diğer sancaklardan aday gösterilen başka isimlere de yer vermiştir (ATASE, ATAZB, 20/206, lef: cd). Miralay Şevket Bey yine aynı tarihlerde Sivas'a gönderdiği başka bir şifrede Mustafa Kemal Paşa'ya Trabzon sancağından Sulh ve Selâmet Fırkası memurlarından Hacı Fazıl Efendi'nin aday gösterildiğini bildirmiş, telgrafında ayrıca bu firkadan aday gösterilen isimlerin birçoğunun Temsil Heyeti namına çalışmasının temin edildiğini de belirtmiştir (ATASE, ATAZB, 20/206, lef: ce).

Görüldüğü gibi sancaktan sürpriz isimler aday olmuştur. Ancak sürprizler bununla sınırlı kalmamış ve sancaktan bazı isimler hakkında Sivas'a beklenmedik haberler gitmiştir. Harbiye Nazırı Cemal Paşa 17 Kasım 1919 tarihinde Mustafa Kemal Paşa'ya bir telgraf çekerek bazı isimlerin İstanbul Hükûmeti tarafından mebus seçilmesinin istenmediğini bildirmiştir. Bu isimler arasında Trabzon sancağından eski mebus Hafız Mehmet Efendi'nin ismi de bulunmaktadır. Nitekim bunun sebebi hakkında malumatta bulunmamıştır. Sadece telgrafında Mustafa Kemal Paşa'dan bu isimler hakkında gerekenin yapılmasını istemiştir (ATASE, ATAZB, 20/206, lef: cp).

Cemal Paşa ve Mustafa Kemal Paşa arasında yapılan bu görüşmeden sonra Mustafa Kemal Paşa Ankara'da Ali Fuat Paşa'ya gönderdiği şifrede hem durumu anlatmış hem de meclisin İstanbul'da toplanmasının sakıncalarından bahsetmiştir. Şifrede ayrıca seçimler bittikten sonra mebusların İstanbul'a gitmeden önce bir kısmının Eskişehir'de, bir kısmının da Trabzon ve Samsun'da toplanmasına karar verildiği bildirmiştir. Kendisinden bu konu ile alakalı gerekli tedbirleri almasını ve mebusların belirlenen noktalara ulaşması için gerekenleri yapmasını istemiştir. Bunun üzerine Ali Fuat Paşa mebusların İstanbul'a gitmeden evvel Eskişehir ve Trabzon'da toplanacakları yerler hakkında Trabzon sancağında Müdafaa-i Hukuk Cemiyeti merkezleri ile gerekli görüşmeleri yapmaya başlamıştır (TITE, 1599/G:313, lef: 28). 
Aslihan KILINÇ

Son Osmanlı Mebusan Meclisi Seçimlerinde Trabzon Sancağ

(İttihatç1-İtilafçı Mücadelesi)

Görüşmeler devam ederken Mustafa Kemal Paşa, seçilmesini istemediği isimleri belirlemiştir. Bunlar Sivas Kongresi’ne katılmaya itiraz eden eski Trabzon mebusları İzzet ve Servet Beylerdir. Mustafa Kemal Paşa bu konuda Halit Bey’le iletişime geçmiş, Halit Bey’den bu iki ismin seçilmemesi için gerekenin yapılmasını istemiştir. Halit Bey, İzzet ve Servet Beylerin adaylıklarını engellemek için aldığı tedbirleri 26 Ekim 1919'da çektiği telgrafla Mustafa Kemal Paşa'ya iletmiştir. Halit Bey, 22 Kasım 1919 tarihinde Mustafa Kemal Paşa'ya tekrar bir telgraf yollayarak her ne kadar Trabzon'da İzzet ve Servet Beyler tarafında toplanmış bir zümre olsa da seçimleri Temsil Heyeti adaylarının kazanmasının beklendiğini bildirmiştir (Üçüncü, 2019). Seçimlerde Kasım ayının sonlarına gelinmiş ve Trabzon halkı kendi adaylarını belirlemiştir. Aralarında aldıkları kararla Kâzım Karabekir Paşa'dan Trabzon'dan aday olmasını istemişler ancak o Trabzonlulara bir asker olarak daha iyi hizmet edebileceğini belirterek teklifi geri çevirmiştir. Bunun üzerine Trabzon halkı yeni adaylarını seçmiştir. Buna göre Mardin eski mebusu Trabzonlu İhsan Bey, Canik Maarif Müdürü Mustafa Zihni, Rize Bidayet Ceza Mahkemesi'nin eski reisi Giresunlu Ahmet Lemi, Vakfikebir Ceza Mahkemesi Reisi Ali Rıza, Bahriye'den emekli Ali Şükrü, Şeyh Ali Naki, Nafia Müsteşarı Ahmet Muhtar Bey, Nemlizade Mithat, Nebizade Hamdi, Trabzon eski mebusu Hafız Mehmet, mazul kaymakam Ordulu Hacı Alizade İsmail, İstanbul Sultani Mektebi Arabi Muallimi Trabzonlu Gürcüzade Mahmut Celalettin, Sulh ve Selamet Heyet-i azasından Sürmeneli Hoca Ahmet Fazıl, Trabzonlu Hüseyin Yazıcızade, Mustafa Lütfi, İzmir merkez hastanesi baştabip vekili binbaşı Semercizade Hasan Sükûti, eski maarif müsteşarı Abdullah, Hısnımansur eski kaymakamı Fahrettin, Mülkiye Mektebi muallimlerinden Hasan, Erkan'ı Harp Kaymakamı ve Bahriye Erkan-1 Harp mütekaitlerinden Ali Şükrü Bey, Giresun kazası eşrafından Dizdarzade Eşref ve Ordu kazasından Karahisar Mutasasarrıfı Refet Bey halk tarafından Trabzon sancağından aday gösterilmiştir. Dönemin gazeteleri de seçimleri yakinen takip etmektedir. Nitekim 17 Aralık 1919 tarihiyle seçimlerin bittiğini ve seçim sonuçlarını ilan ederler. Gazetelerde verilen bilgilere göre Sürmene, Akçaabat ve Of kazalarında Mülkiye Mektebi muallimlerinden Hasan Bey’le, Hüsrev Bey, Ali Şükrü Bey'le Eşref Bey, Şefik Bey’le Ahmet Muhtar ve Edirne Kadısı Süleyman Sırrı Bey oyların çoğunluğunu almıştır. Vakfikebir kazasında yapılan seçim sonuçlarına göre halkın çoğunluğu eski mebus Servet Bey, eski mebus Eyüpzade İzzet Bey, Hasan Hüsnü Bey, Ali Şükrü Bey, Sarızade Ömer Efendi, Vakfıkebir Ceza Reisi Ali Rıza Efendi, Hüseyin Kaptanzade Yusuf Ziya Efendi'nin seçilmesi için oy kullanmıştır. Bu sonuçlara göre Trabzon sancağından Nafia Müsteşarı Ahmet Muhtar Bey (247), Sakizade Hasan Bey (305), Efendizade Ali Şefik Bey (229), Reiszade Ali Şükrü Bey (234), Hüsrev (Gerede) Bey (199), Dizdarzade Eşref Bey (175), Ordu'lu İsmail Bey (179) aldıkları oylarla Son Osmanlı Mebusan Meclisi’ne seçilmeyi başarmıştır (Özel,1991; Vakit, 16 Kanun-1 Evvel 1335, 733; Yenigün, 12 Kânunusani 1336, 297). 
Seçimler bitmiş ve Trabzon halkı mebuslarını belirlemişti. Nitekim Temsil Heyeti ve Mustafa Kemal Paşa sancaktan istediği desteği tam anlamıyla bulamamıştı. Temsil Heyeti bu sonuçlara rağmen seçimin peşini bırakmamış ve mebusların meclise gitmeden önce belirledikleri bölgede toplanması için çalışmaları hızlandırmıştı. Zira Kâzım Karabekir Paşa 7 Aralık 1919 tarihinde Erzurum, Van ve Trabzon heyet merkezlerine gönderdiği telgraflarla bu bölgelerden seçilen mebusların İstanbul'a gitmeden önce Trabzon'da toplanmaları, burada son durumu istişare etmeleri ve daha sonra İstanbul'da açılacak meclise katılım yapmalarını istemişti (ATASE, ATAZB, 23/46, lef: cj). Burada amaç her ne kadar 1919 y1lı seçimlerinde Temsil Heyeti adına seçilen mebuslar çoğunlukta olsa da diğer mebusların milli amaç ve esaslara uyması için görüş birliği sağlamaktı. Bu toplantıya Trabzon mebuslarının katılıp katılmadıkları hakkında net bilgi bulunmamaktadır.

Sıra mebusların İstanbul'a doğru yola çıkmasına gelmiş̧tir. Ancak seçimlerde hile yapıldığına dair şikâyetler olmuştur. Seçimlerin bitmesinden yaklaşıl bir ay evvel başlayan bu şikâyetler seçimlerin bitmesiyle daha da artmış ve son durum Dâhiliye Nezareti'ne bildirilmiştir. 29 Aralık 1919 tarihinde Fevzi Paşa idaresindeki teftiş heyeti “Trabzon'dan Darulhikme A'zâsından Mustafa Tevfik, Mahkeme-i Temyîz A'zâsından, Cafer ve Ferik Fevzi Paşa” imzasıyla Dâhiliye Nezareti'ne gönderdiği bir şifrede dokuz gün boyunca Trabzon'da vapur beklediklerini, şiddetli firtına nedeniyle telgraf tellerinin arızalandığını ve dört gün boyunca iletişimin koptuğunu bu sebeple durumu haber edemediklerini bildirmiştir. Bu süre zarfinda Trabzon merkezde mebus seçimlerine müdahale edildiğine dair bir malumat almadıklarını, buna mukabil merkeze bağlı Maçka kazasında yapılan seçimlerde ise "çirkinliklerle mâlamâl olduğu istihbâr edildiği..." şeklinde suistimal ve seçime müdahale olduğuna dair bilgi aldıklarını belirtmiştir. Edindikleri bilgiye göre Trabzon'da ikamet eden, aynı seçimde kazadan seçilen müntehib-i sanilerden Hamdi Bey'in seçilen diğer müntehib-i sanileri tehdit ettiğini öğrendiklerini ve durumun Dâhiliye Nezareti'ne iletilmek üzere şikâyet dilekçesi ile vilayete iletildiğini bildirmiştir. Ancak bu şikâyet hakkında vilayetin hiçbir önlem almadığından bahsetmiştir. Ayrıca gelişen olaylarda diğer müntehib-i sânîlerin yazılı ve sözlü olarak seçim bölgelerine dağıtılan evraklarda bahsi geçen kişiyi seçmedikleri takdirde haklarında birçok zarara uğrayacakları ve Erzurum'a sevk edilecekleri yolundaki tehditlere maruz kaldıklarının belirlendiğini yazmıştır. Dahası askerlerin tehdit ve bunaltmasıyla seçmenlerin her birinin diğeriyle görüşmesi kesinlikle engellenmiş, 21 müntehibi saniden 17'sinin seçim pusulasının ittihatçılar tarafından silah ve bıçakla tahrip edildiği bildirilmiştir. Belgeler tahrip edildikten sonra pusuladaki isimlerin seçildiği yolunda sandıklara uydurulmuş pusulaların atıldığı belirtmiştir. Tehdit edenlerin mahallî fırka kumandanı Kaymakam Halit Bey'e, Esad ve Osman Efendi adına iki teğmen tarafından yapıldığı anlaşılmış olduğundan seçime fesat karıştırıldığı hakkında hazırlanan evrakların nezarete bildirildiği ve 
Aslıhan KILINÇ

Son Osmanlı Mebusan Meclisi Seçimlerinde Trabzon Sancağı

(İttihatç1-İtilafçı Mücadelesi)

Giresun kazasında da durumun seçime müsait olmadığı belirtilmiştir. Bununla birlikte heyet raporunda teftiş ettikleri Erzurum ve Sivas bölgelerindeki seçimlere nazaran Trabzon seçimlerinde İttihatçıların çok daha baskın olduğunun bariz olarak görüldüğü eklenmiştir (BOA, DH. İ.UM. EK. 116/61, lef: 1-2-3; BOA. DH. İ.UM. EK. 82, lef: 4).

Aslında heyet raporunda da belirtildiği üzere Trabzon seçimlerinde yapılan usulsüzlükler hakkında seçimler devam ederken Dâhiliye Nezareti'ne şikâyet dilekçeleri gitmiş ancak gereken cevap alınamamıştır. Seçim heyetinin bölgeye gelmesinden sonra olaylar su yüzüne çıkmıştır. Dâhiliye Nezareti'ne Kasım ayı içerisinde Trabzon'dan çekilen bir telgrafta Maçka seçimleri hakkında vilayete şikâyette bulunulduğu bunun üzerine bölgeye tahkik heyeti geldiği ve seçimin her türlü müdahaleden uzak yapılması için kaymakamlığa tebligat gönderildiği bildirilmiştir. Bunun yanı sıra nezarete çekilen telgraflardan bazılarında olayın tamamıyla, şikâyetlerde yer alan mebus adaylarının ve onların taraftarları arasındaki rekabetten ibaret olduğu, seçimlere bir müdahale olmadığı, gerekli tedbirlerin de alındığı belirtilmiştir (BOA, DH. İ.UM. EK.116/61, lef: 4). Bu süre zarfinda geçen üç hafta boyunca seçimlere müdahale olduğu şeklinde başka bir şikâyet ve müracaat olursa vilayete bildirilmesiyle tahkikat için seçim bölgesine heyet gönderileceği ve sonucun nezarete bildirileceği belirtilmiştir (BOA, DH. İ.UM. EK. 116/61, lef: 5-6). Bu olaylar üzerine 30 Aralık 1919 tarihinde Dâhiliye Nezareti'nde Şerif Paşa'dan Sadrazam Ali Rıza Paşa'ya, Harbiye Nazırı Cemal Paşa'ya, Trabzon vilâyetinde Müdür Nazmi Bey’e ve Heyet-i Teftişiye Müdürü Fethi Bey’e iletilmek üzere bir telgraf çekilmiş ve Maçka seçimlerinde yapılan usulsüzlükler ayrıntısıyla bildirmiştir. Bu olaylar üzerine teftiş heyetinin hazırladığı raporda ise Maçka kaymakamlığından 29 Aralık 1919'da alınan telgrafta seçimin güven içerisinde yapılması için gerekli önlemlerin alındığı ve kaymakamlıktan vilayete şikâyet dilekçesi yollanmadığı bildirilmiştir (BOA, DH. İ.UM. EK. 116/61, lef: 8).

Seçim tartışmaları devam ederken müfettişlerden Hilmi Bey rahatsızlanmış ve 1 Ocak 1920'de Ordu'dan hareket ederek İstanbul'a dönmek zorunda kalmıştır (BOA, DH. İ.UM. EK. 82, lef: 1). Hilmi Bey'in durumu 3 Ocak 1920 tarihinde Trabzon'dan Dâhiliye Nezareti'ne çekilen bir telgrafla bildirilmiş, telgrafta ayrıca seçimi teftiş için vilâyete münasip ve tarafsız bir merkezden yeni bir müfettiş görevlendirildiği, son sözün nezarete ait olduğu belirtilmiştir (BOA, DH. İ.UM. EK. 82, lef: 2; BOA, DH. İ.UM. EK. 82, lef: 4). Seçimlere hile karıştırıldı̆̆ iddiası meclisin 12 Ocak 1920 tarihinde açılmasından sonra da devam etmiştir. 9 Şubat 1920'de yapılan oturumda Trabzon mebuslarının seçimlere hile karıştırdığı gündeme gelmiş ve bazı itirazlar olmuşsa da mazbataları onaylanarak mebuslukları kabul edilmiştir. (Meclis-i Mebusan Zabıt Ceridesi,8-9 Şubat 1336, 67-68).

16 Mart 1920 tarihinde İstanbul'un İngilizler tarafından işgal edilmesi ve meclisin kapatılmasından sonra Temsil Heyeti tarafından 19 Mart 1920'de bir tamim yayımlanmıştır. 
Vilayet ve kolordulara gönderilen tamimde, Ankara'da olağanüstü yetkilerle donatılmış bir meclisin toplanması için yeniden secim yapılması istenmiş; yapılan seçimler sonunda TBMM açılmıştır (Harp Tarihi Vesikaları Dergisi, Eylül 1955,337).

\section{Sonuç}

Osmanlı Devleti'nde Milli Mücadele döneminde yaşanan en önemli gelişmelerden birisi Mebusan Meclisi seçimlerinin yapılması olmuştur. Zira I. Dünya Savaşı'nın sona ermesinden sonra Osmanlı Devleti kendi içinde birliği sağlamaya çalışırken İtilaf Devletleri ise bu süre zarfinda oldukça ağır şartları olan Mondros Mütarekesi'ni bahane ederek Anadolu’yu işgal etmeye başlamıştır. İstanbul Hükûmeti ise İtilaf Devletleri tarafından yapılan bu işgallere sessiz kalmayı tercih etmiştir. Mustafa Kemal Paşa ve Temsil Heyeti bu süreçte hem işgallere karşı mücadele vermiş hem de meclisin bir an evvel açılması için çalışmalara başlamıştır. Bununla birlikte Temsil Heyeti sadece düşman işgalleri ile değil aynı zamanda ülke içerisindeki bölücü unsurlarla da uğraşmak zorunda kalmıştır. Bu unsurlara en büyük desteği veren ise yine İstanbul Hükûmeti'nin kendisi olmuştur. Arşiv kayıtları, süreli yayınlar ve ilk elden kaynaklardan yapılan araştırmalara göre Temsil Heyeti için hayati önem arz eden yerler arasında bulunan Doğu Karadeniz Bölgesi'nde seçimlerin oldukça çekişmeli geçtiği görülmektedir. Seçimlere İttihatç1İtilafçı mücadelesi damgasını vurmuş, süreçte yaşanan olaylar Temsil Heyeti ve İstanbul Hükûmeti'ni uzun süre meşgul etmiştir. Sakizade Hasan Bey, Nafis Müsteşarı Ahmet Muhtar Bey, Reiszade Ali Şükrü, Efendizade Ali Şefik Bey, müstafi Kaymakam Hüsrev (Gerede) Bey, Ordulu İsmail Bey, Dizdarzade Eşref Beylerin mebus olarak seçildiği Trabzon'da, Mustafa Kemal Paşa istediği başarıyı elde edememiştir. Bilhassa Maçka, Giresun, Tirebolu kazalarında yapılan seçimlere hile karıştırıldığına dair Trabzon vilayetine ve Dâhiliye Nezareti'ne birçok şikâyet dilekçesi yazılmış, sorunun çözümü adına bölgeye teftiş heyeti gelmiştir. Nitekim teftiş heyetinin verdiği rapor ve meclis tutanaklarında görüldüğü üzere seçimlerin iptali ya da yeniden yapılması söz konusu olmamıştır. Bunun üzerine Trabzon sancağından seçilen yedi mebusun mazbataları 1920 Ocak ayı içerisinde mecliste onaylanmış ve mebuslukları kabul edilmiştir. Ancak Trabzon seçimlerine hile karıştırıldı ğı iddiası meclisin işgal edilmesine kadar tartışılmıştır. Nitekim meclisin işgali ve dağıtılmasından sonra iddialar askıda kalmıştır.

Sonuç olarak 1919 yılı Mebusan Meclisi'nin çoğunluğunu Müdafaa-i Hukuk Cemiyeti üyelerinin oluşturması yabancı basın da dâhil birçok yerde Mustafa Kemal Paşa ve Temsil Heyeti'nin zaferi olarak kabul edilmiştir. Ayrıca şunu da belirtmek gerekir ki 1919 Mebusan Meclisi sadece 12 Ocak 1920-16 Mart 1920 arasında çok kısa süreli faaliyet gösterebilmiş bir meclis olarak değerlendirmek yanlış olur. Zira bu meclisin açılması yok olmak üzere olan bir cihan imparatorluğunun Türkiye Cumhuriyeti Devleti olarak yeniden ayağa kalkması anlamına geldiği için oldukça önemlidir. 
Aslihan KILINÇ

Son Osmanlı Mebusan Meclisi Seçimlerinde Trabzon Sancağı

(İttihatç1-İtilafçı Mücadelesi)

\section{Kaynakça}

\section{Arşiv Belgeleri}

ATASE, ATAZB, 2/131, lef:1.

ATASE, ATAZB, 9/40, lef:1-5.

ATASE, ATAZB, 9/52, lef:8.

ATASE, ATAZB, 19/23, lef:1.

ATASE, ATAZB, 20/206.

ATASE, ATAZB, 20/206, lef: aa.

ATASE, ATAZB, 20/206, lef: af.

ATASE, ATAZB, 20/206, lef:ag.

ATASE, ATAZB, 20/206, lef: ah.

ATASE, ATAZB, 20/206, lef: bf.

ATASE, ATAZB, 20/206, lef: bo.

ATASE, ATAZB, 20/206, lef: cd.

ATASE, ATAZB, 20/206, lef: ce.

ATASE, ATAZB, 20/206, lef: cp.

ATASE, ATAZB, 23/46, lef: aj.

ATASE, ATAZB, 20/206, lef:ap.

ATASE, ATAZB, 20/206, lef:apa.

ATASE, ATAZB, 23/46, lef: bi.

ATASE, ATAZB, 23/46, lef: ci.

ATASE, ATAZB, 23/46, lef: cj.

ATASE, ATAZB, 34/73, lef:1.

BOA, BEO. 4598/344833, lef: 1.

BOA, MV.217/129, lef: 1.

$B O A$, DH. KMS. 57/37, lef: 1.

BOA, DH. İ.UM. EK. 113/10, lef: 6.

BOA, DH. İ.UM. EK. 114/39, lef: 5.

BOA, DH. İ.UM. EK. 116/61, lef: 1-2-3.

BOA, DH. İ.UM. EK. 82, lef: 4. 
BOA, DH. İ.UM. EK. 116/61, lef: 5.

BOA, DH. İ.UM. EK. 116/61, lef: 6.

BOA, DH. İ.UM. EK.116/61, lef: 4.

BOA, DH. İ.UM. EK. 82, lef: 2.

BOA, DH. İ.UM. EK. 116/61, lef: 7.

BOA, DH. İ.UM. EK. 116/61, lef: 8.

BOA, DH. İ.UM. EK. 82, lef: 1.

BOA, DH. ŞFR.644/34, lef: 1-2.

TITE, 13/17, lef:1-2.

TITE, 18/83, lef: 1 .

TITE, 295/35000, lef: 1 .

TITE, 297/82, lef: 1.

TITE, 297/49, lef: 1.

TITE, 1599/G:313, lef: 28.

\section{Gazete ve Süreli yayınlar}

Alemdar, 1 Teşrinievvel 1335.

Alemdar, 29 Teşrinievvel 1335.

İkdam, 18 Teşrinievvel 1335.

Vakit, 29 Teşrinievvel 1335.

Vakit, 16 Kanun-1 Evvel 1335.

Yenigün, 21 Teşrinievvel 1335.

Yenigün, 24 Teşrinievvel 1335.

Yenigün, 26 Teşrinievvel 1335.

Yenigün, 27 Teşrinievvel 1335.

Yenigün, 12 Kânunusani 1336.

Meclis-i Mebusan Zabıt Ceridesi, C. 1, D. 3, İçs.1, İn.1, 1 Mayıs 1330.

Meclis-i Mebusan Zabıt Ceridesi, C. 1, D. 4, İçs.1, İn.8, 9 Şubat 1336.

Harp Tarihi Vesikaları Dergisi, sayı:11, Aralık 1954, vesika.279.

Harp Tarihi Vesikaları Dergisi, sayı:13, Eylül 1955, vesika.337.

Harp Tarihi Vesikaları Dergisi, sayı:87, Şubat 1989, vesika.2087.

\section{Telif Eserler}


Aslihan KILINÇ

Son Osmanlı Mebusan Meclisi Seçimlerinde Trabzon Sancağ

(İttihatçı-İtilafçı Mücadelesi)

Akbal İ., (2008). Milli Mücadele Döneminde Trabzon'da Muhalefet. Serander Yayınları, Trabzon.

Akbal İ., (2004). 1919-1923 Yılları Arasında Muhalif Kimliğiyle Trabzo. Ankara Üniversitesi Sosyal Bilimler Enstitüsü, Yayımlanmamış Doktora Tezi, Ankara.

Akcan E. ve Geçikli, R. M. (2017). Milli Mücadele'de Artin Cemal ve Faaliyetleri. Ankara Üniversitesi Türk İnkllâp Tarihi Enstitüsü Atatürk Yolu Dergisi, 60, 1-22.

Akyıldız A.,(2003). Meclis-i Mebusan, TDV İslâm Ansiklopedisi, 28, İstanbul, 245-247.

Atatürk, M. K., (2016). Nutuk, 12. Basım, Ankara: Türkiye İș Bankası Kültür Yayınları.

Aybars E., (1984). Trabzon Muhafaza-i Hukuk-u Milliye Cemiyeti ve Ali Sait Paşa Tahkik Heyeti. Tarih Incelemeleri Dergisi, 2 (1), 159-201.

Aygün N., (2010). Osmanlı Devleti’nde İdarî Taksimat Alanındaki Düzenlemelerin Taşradaki Yansımaları: Vakfikebir, Şarlı ve Tonya Örneği (1840-1918), Karadeniz Araştırmaları Dergisi, 26, 35-77.

Bilgen B., (2011). Dönemin Basınına Göre 1919 seçimleri ve Meclis-i Mebusan'ın Oluşturulması, Yayımlanmamış Yüksek Lisans Tezi, Trakya Üniversitesi Sosyal Bilimler Enstitüsü, Edirne.

Bilgin T., (2015). Son Osmanlı Mebusan Meclisi Seçimleri ve İzmit Mebusları. Uluslararası Gazi Akça Koca ve Kocaeli Tarihi Sempozyumu, 2, 1115-1126.

Birinci, A., (1998). Hürriyet ve İtilaf Fırkası, TDV İslâm Ansiklopedisi, 18, İstanbul, 507-511.

Boyacıŏlu R., (2002). Erzurum'dan Sivas Kongresi'ne, Sivas Kongresi Uluslararası Sетроzуити (2-4 Eylül 2002-Sivas).

Çavdar T., (2004). Türkiye'nin Demokrasi Tarihi 1839-1950, Üçüncü basım, Ankara: İmge Kitabevi Yayınları.

Çelik R., (2013). Trabzon'da Siyasi Hayat (1920-1950), Yayımlanmamış Doktora Tezi, Karadeniz Teknik Üniversitesi Sosyal Bilimler Enstitüsü, Trabzon.

Demiryürek H., (2018). Kütahya Sancağında 1919 Osmanlı Meclis-İ Mebusan Seçimleri. MCBÜ, Sosyal Bilimler Dergisi, 16(3), 519-544.

Erdeha K., (1975). Milli Mücadelede Vilayetler ve Valiler, İstanbul: Remzi Kitabevi.

Güneş İ., (2012). Meşrutiyetten Cumhuriyete Türkiye'de Hükûmetler Programlart ve Meclisteki Yankıları (1908-1923), İstanbul: Türkiye İş Bankası Kültür Yayınları.

İlyas A., (2013). Heyet-i Temsiliye'nin Siyasal Yapılanması. Tarihin Peşinde Uluslararası Tarih ve Sosyal Araştırmalar Dergisi, 5(9), 19-44.

Kansu M. M., (2019). Erzurum 'dan Ölümüne Kadar Atatürk'le Beraber, Ankara: TTK Yayınlar1. Karabekir K., (2016). İstiklal Harbimiz, 6. Bask1, Ankara: Yap1 Kredi Yayınları. 
Karaca T. N., (2004). Meclis-i Mebusan'dan Türkiye Büyük Millet Meclisine Geçiş Sürecinde Son Osmanlı Meclis-i Mebusan Seçimleri, Ankara: TTK Yayınları.

Karpat K., (2010). Osmanlı Nüfusu (1830-1914), İstanbul: Timaş Yayınları.

Okur M., (2014). Osmanlı Devleti'nin Son Yüzyılında Karadeniz Bölgesi'nde Türk, Rum ve Ermeni Nüfusu, Tarihte Türkler ve Ermeniler, Ankara, 1-33.

Özel S., (1991). Milli Mücadele’de Trabzon, Ankara: Türkiye İş Bankası Kültür Yayınları.

Tosun R., (1996). Milli Mücadelede Sivas'ın Yeri ve Önemi. Atatürk Araştırma Merkezi Dergisi, $12(34), 67-86$.

Tunaya T. Z., (2015). Türkiye'de Siyasal Partiler, (II. Meşrutiyet Dönemi), I, İstanbul: İletişim Yayınlar1.

Tunç A., (2019). Alemdâr Gazetesine Göre İstiklâl Savaşı'nda İç Politika (1919-1921) Yayımlanmamış Doktora Tezi, İnönü Üniversitesi Sosyal Bilimler Enstitüsü, Malatya.

Ural, S., (2007). Mütareke Döneminde Trabzon Vilayetinin Sosyal Ve Ekonomik Durumunu Düzeltmeye Yönelik Çalışmalar. Atatürk Üniversitesi Türkiyat Araştırmaları Enstitüsü Dergisi (TAED), 32, 269-287.

Uyar H. ve Korkmaz, Ç. C. (2015). Birinci ve İkinci Dünya Savaşı'nın İşbirlikçi Hükûmetleri: Damat Ferit Paşa ve Vichy Hükûmetleri. Belgi Dergisi, 10 (10), 1331-1341.

Üçüncü U., (2006). Milli Mücadele Döneminde Trabzon'da İttihatçılık, Yayımlanmamış Yüksek Lisans Tezi, Karadeniz Teknik Üniversitesi Sosyal Bilimler Enstitüsü, Trabzon.

Üçüncü U., (2019). Gümüşhane'de Son Osmanlı Mebusan Meclisi Seçimleri, History Studies, 11 (4), 1381-1391.

Yiğit Y., (2014). İttihat Ve Terakki Fırkası İçinde Parti İçi Muhalefet: Hizb-İ Cedit Hareketi. Çağdaş Türkiye Tarihi Araştırmaları Dergisi, Journal Of Modern Turkish History Studies, 14 (28), 103-125. 